Boletín de la Sociedad Botánica de México 48: 3-11, 1988

DOI: $10.17129 /$ botsci.1340

Bol. Soc. Bot. México 48: 3-11 (1988)

\title{
Distribución de Rhynchosporium secalis en el mundo y en México
}

\author{
Magda Carvajal Moreno ${ }^{1}$
}

\begin{abstract}
RESUMEN. En el presente trabajo se hace una revisión de la distribución de Rhynchosporium secalis (Oud.) Davis, hongo causante de la escaldadura de la cebada, ya que esta enfermedad es de gran importancia para dicho cultivo. El hongo mencionado es de amplia distribución mundial y se encuentra por lo menos en 34 países. En México se encuentra en la parte central del país en los estados de Hidalgo, Puebla, Tlaxcala, México, Jalisco, Zacatecas, Veracruz, Guanajuato, Aguascalientes y Querétaro. También ataca a la cebada del norte de México, causando bajas en Ensenada y Baja California Norte.
\end{abstract}

ABSTRACT. The present work is a review of the distribution of Rhynchosporium secalis (Oud.) Davis, causal fungus of barley leaf blotch, because this disease is of great importance to the mentioned crop. This fungus is of worldwide distribution and it is present in 34 countries at least. In Mexico, it is found in the central part of the country, in the states of Hidalgo, Puebla, Tlaxcala, Mexico, Jalisco, Zacatecas, Veracruz, Aguascalientes and Querétaro. It also attacks the barley of the northern part of Mexico, causing damage in Ensenada and North Baja California.

La escaldadura de la cebada es una de las enfermedades más importantes de este cultivo y reduce la producción de este cereal en forma severa. Se manifiesta con manchas o lesiones romboides de color azul grisáceo cuando jóvenes y amarillas con borde café cuando maduran, en hojas, semillas, tallo y glumas. Esta enfermedad se puede observar en todos los estados de crecimiento de la cebada, siendo más drástica en las plántulas. Los síntomas de la escaldadura se pueden observar en la figura 1.

Es muy importante hacer una revisión de la distribución de este patógeno, dado que se transmite tanto por rastrojo infectado como por semilla; conocer los países donde existe permite importar semilla de cebada sin correr el riesgo de introducir más escaldadura. Además, el identificar la distribución mundial y nacional de Rhymchosporium secalis, permitirá establecer cuarentenas externas e internas cuando sea necesario.

${ }^{1}$ Departamento de Botánica, Instituto de Biología, Universidad Nacional Autónoma de México. Apdo. Postal 70-233; Delegación Coyoacán; 04510, México, D.F.

Carvajal-Moreno M. 1988. Distribución de Rhynchosporium secalis en el mundo y en México. Boletín de la Sociedad Botánica de México 48: 3-11. 


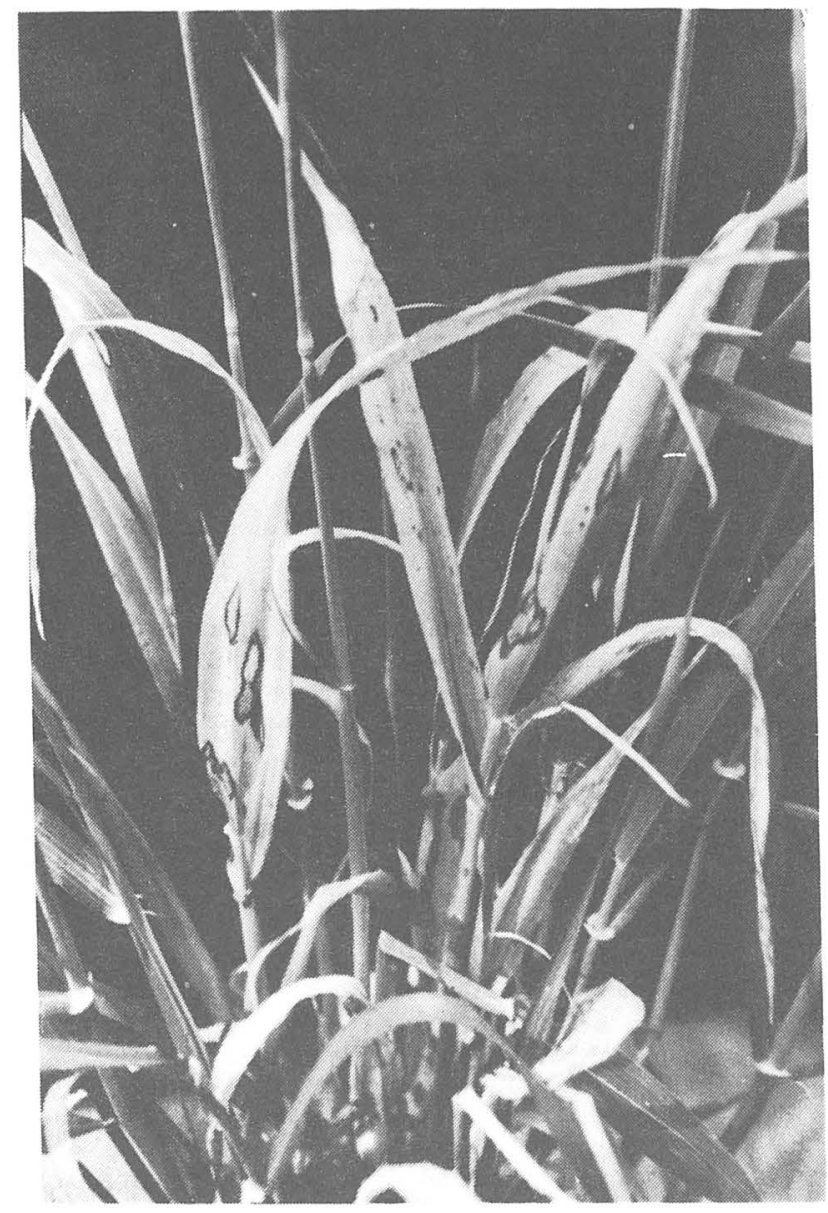

Figura 1. Síntomas de escaldadura de la cebada. Se pueden observar las lesiones romboides de centro claro y bordes más oscuros en las hojas de la variedad Porvenir, en México.

Este hongo tiene una distribución mundial en 34 países cuando menos, ya que se localiza tanto en regiones tropicales como polares, puesto que se adapta a los diferentes climas. Es posible que éste se encuentre en otros países pero que no se haya reportado su existencia. En la tabla 1 se indican los lugares donde se ha reportado la presencia de escaldadura de la cebada. A continuación describiremos con más detalle estos países:

En la Unión de Repúblicas Soviéticas Socialistas (URSS), donde hay más informes de la presencia del hongo es en Ucrania, que está en el suroeste, y en Leningrado y en Kiev, que están en la parte media occidental (Drapatyi, 1978; Drapatyi, 1979; Peresypkin y Drapatyi, 1977 y 1978). 
En Gran Bretaña aparece en todo el país, desde el norte de Escocia (Shipton et al., 1981), hasta Gales e Inglaterra (Priestley y Bayles, 1979) y en el suroeste, donde causa graves daños al cultivo (Marshall et al., 1971).

De Canadá reportan su existencia en la isla Prince Edward en 1978 (Clough y Sanderson, 1979); en 1977 había aumentado su severidad en las provincias marítimas, en el oeste de Ontario (Clark, 1978) y en el sur y centro de Alberta (Harper y Piening, 1974).

En Checoslovaquia ataca los distritos al pie de los cerros y con clima húmedo y frío (Liska, 1975).

En Australia se localiza en el sur (Mayfield y Clare, 1978) y en el oeste (Khan y Portmann, 1979).

En Finlandia el hongo se diseminó en la cebada de primavera de todo el país, siendo más común en variedades de seis hileras con relación a las de dos. También se presentó en el centeno de invierno, donde esporuló abundantemente en las hojas en primavera y principios de verano. También se vio la enfermedad en Laponia (Makela, 1972 y 1974).

Es interesante señalar el amplio rango de temperatura del hongo que se distribuye desde regiones glaciares hasta climas templados o cálidos. Un factor importante para la propagación de la escaldadura de la cebada es la cantidad de agua, ya que entre más llueva se distribuye mejor y con más rapidez, de modo que puede decirse que la cantidad de agua es un factor más determinante para la aparición de la enfermedad que la temperatura.

TABLA 1. Distribución de Rhynchosporium secalis en el mundo

\begin{tabular}{|c|c|c|}
\hline Continente & País & Referencias \\
\hline América & $\begin{array}{l}\text { Argentina } \\
\text { Canadá } \\
\text { Chile } \\
\text { Estados Unidos } \\
\text { México } \\
\text { Perú }\end{array}$ & $\begin{array}{l}65,66 \\
14,15,16,17,28,72 \\
78 \\
30,31,32,49 \\
12,55,64 \\
74\end{array}$ \\
\hline Europa & $\begin{array}{l}\text { Alemania } \\
\text { Bélgica } \\
\text { Checoslovaquia } \\
\text { Dinamarca } \\
\text { Finlandia } \\
\text { Francia } \\
\text { Gran Bretaña } \\
\text { Holanda } \\
\text { Hungría } \\
\text { Italia } \\
\text { Irlanda del Norte } \\
\text { Noruega } \\
\text { Polonia } \\
\text { Rumania } \\
\text { Suecia } \\
\text { Yugoslavia }\end{array}$ & $\begin{array}{l}34,36,37 \\
26,52 \\
42,79 \\
74 \\
44,45 \\
19,58,62 \\
33,38,51,53,57,61,70,75 \\
40 \\
67,76 \\
11,13,63 \\
46,50 \\
24,27,43 \\
8,18,41 \\
9,10 \\
39 \\
71\end{array}$ \\
\hline Asia & $\begin{array}{l}\text { India } \\
\text { Japón }\end{array}$ & $\begin{array}{l}20,21 \\
56\end{array}$ \\
\hline
\end{tabular}


TABLA 1. Concluye

\begin{tabular}{lll}
\hline Continente & País & Referencias \\
\hline \multirow{4}{*}{ Oceanía } & Turquía & 74 \\
& URss & $22,23,59,60,77$ \\
África & Australia & $2,3,4,5,7,35,48,70$ \\
& Nueva Zelandia & 48,68 \\
& Etiopía & 29 \\
& Libia & 54 \\
& Marruecos & 1 \\
& Sudáfrica & 25,73 \\
& Tanzania & 74 \\
& Túnez & 74 \\
\hline
\end{tabular}

Los números de las referencias de la tabla 1 corresponden a los siguientes autores: (1) Acosta, 1973; (2) Ali, 1974; (3) Ali, 1975 a; (4) Ali, 1975 b; (5) Ali, 1981; (6) Andrade Arias, 1980; (7) Australia, Waite Agriculture Research Institute Biennial Report, 1976-1977; (8) Blonska-Pawlak y Kiatkowski, 1980; (9) Bobes y Sfetcu, 1978; (10) Bobes y Sfetcu, 1979; (11) Cappelli y Raggi, 1981; (12) Carvajal, 1981; (13) Ceoloni, 1980; (14) Clark, 1978; (15) Clark et al., 1979; (16) Clough y Johnston, 1978; (17) Clough y Sanderson, 1979; (18) Czembor et al., 1979; (19) Daniau et al., 1980; (20) Dhanraj, 1970; (21) Dixit y Gupta, 1980; (22) Drapatyi , 1978; (23) Drapatyi, 1979; (24) Eggum, 1972; (25) Eisenberg, 1977; (26) Fraselle, 1974; (27) Hansen y Magnus, 1973; (28) Harper y Piening, 1974; (29) Hingorani, 1971; (30) Jackson et al., 1978; (31) Jackson y Webster, 1976 a; (32) Jackson y Webster, 1976 b; (33) Jordan, 1979; (34) Kampe, 1974; (35) Khan y Portmann, 1979; (36) Kiewnick, 1972; (37) Kiewnick, 1977; (38) King, 1977; (39) Kristiansson y Nilsson, 1975; (40) Kuizenga, 1979; (41) Lewartowski y Studzinski, 1973; (42) Liska, 1975; (43) Magnus, 1972; (44) Makela, 1972; (45) Makela, 1974; (46) Malone y McGimpsey, 1977; (47) Marshall et al., 1971; (48) Mayfield y Clare, 1978; (49) McBeath, 1981; (50) McKeec, 1973; (51) McMartin, 1977; (52) Meeus et al., 1978; (53) Melville y Lanham, 1972; (54) Mohamed, 1975; (55) Moreno y Vivar, 1975; (56) Nishihara, 1979; (57) O’Donnell, 1981; (58) Pauvert et al., 1978; (59) Peresypkin y Drapatyi, 1977; (60) Peresypkin y Drapatyi, 1978; (61) Priestley y Bayles, 1979; (62) Rafenomananjara et al., 1979; (63) Ribaldi et al., 1974; (64) Rivera Peña, 1976; (65) Rodríguez Amieva y Frecha, 1972; (66) Rodríguez Amieva et al., 1973; (67) Sdrovich, 1977; (68) Sheridan y Grbavac, 1977; (69) Shipton et al., 1974; (70) Shipton et al., 1981; (71) Siljes, 1980; (72) Skoropad, 1960; (73) Smith, 1937; (74) Sprague, 1950; (75) Stedman, 1978; (76) Takats et al., 1980; (77) Tantsyura et al., 1980; (78) Tollenaar et al., 1970, y (79) Zenisceva y Lekes, 1977.

En Estados Unidos se encuéntra en Alaska (McBeath, 1981), en los estados del norte, en los centrales y en los del noroeste del Pacífico. Ocasionalmente aparece en el este, en el sur (Alabama y Texas) y en California (Jackson et al., 1976 a, b y 1978).

En Nicaragua se encontró el género, pero en maíz y no en cebada (C. de León, 1983, comunicación personal), por lo que no se tomó como registro. En la mayor parte de Sudamérica y Centroamérica se siembra menos cebada y además no hay reportes al respecto.

Australia y Nueva Zelandia, que tienen gusto por la cerveza, poseen un gran adelanto científico que les permite ofrecer un registro completo de los lugares donde se encuentra la escaldadura de la cebada. Es interesante hacer notar que la influencia anglosajona 
es un factor histórico determinante en el cultivo de la cebada en diferentes países.

Se puede considerar que en la India hay escaldadura, aunque se reporta la enfermedad con un error en la etiología, ya que (Dhanraj, 1970; Dixit y Gupta, 1980) señalan a Alternaria alternata como causa de la escaldadura de la cebada, y este error se debe a que el hongo mencionado anteriormente casi siempre está asociado con Rhynchosporium secalis, de ahí uno de los problemas más importantes para la purificación del segundo. Además, $R$. secalis es un hongo de crecimiento sumamente lento en los diferentes medios de cultivo y Alternaria es rápido; por tanto, es explicable que se hayan equivocado en el aislamiento del patógeno, o bien que en las pruebas de patogenicidad hayan inoculado ambos hongos sin darse cuenta, y reaislaron sólo a Alternaria.

En la figura 2 se puede apreciar la distribución de los lugares que han reportado la existencia de Rbynchosporium secalis y la escaldadura de la cebada.

En la República Mexicana, la escaldadura de la cebada se encuentra en la costa de Ensenada, Baja California, donde los cultivos de cebada de invierno ocupan una superficie de 30000 hectáreas. La brisa húmeda de esa región favorece el desarrollo de la enfermedad (M. Navarro, 1982, comunicación personal).

En la Mesa Central, donde se siembran alrededor de 200000 hectáreas de cebada al año, se encuentra escaldadura en los estados de Hidalgo, Puebla, Tlaxcala, México,

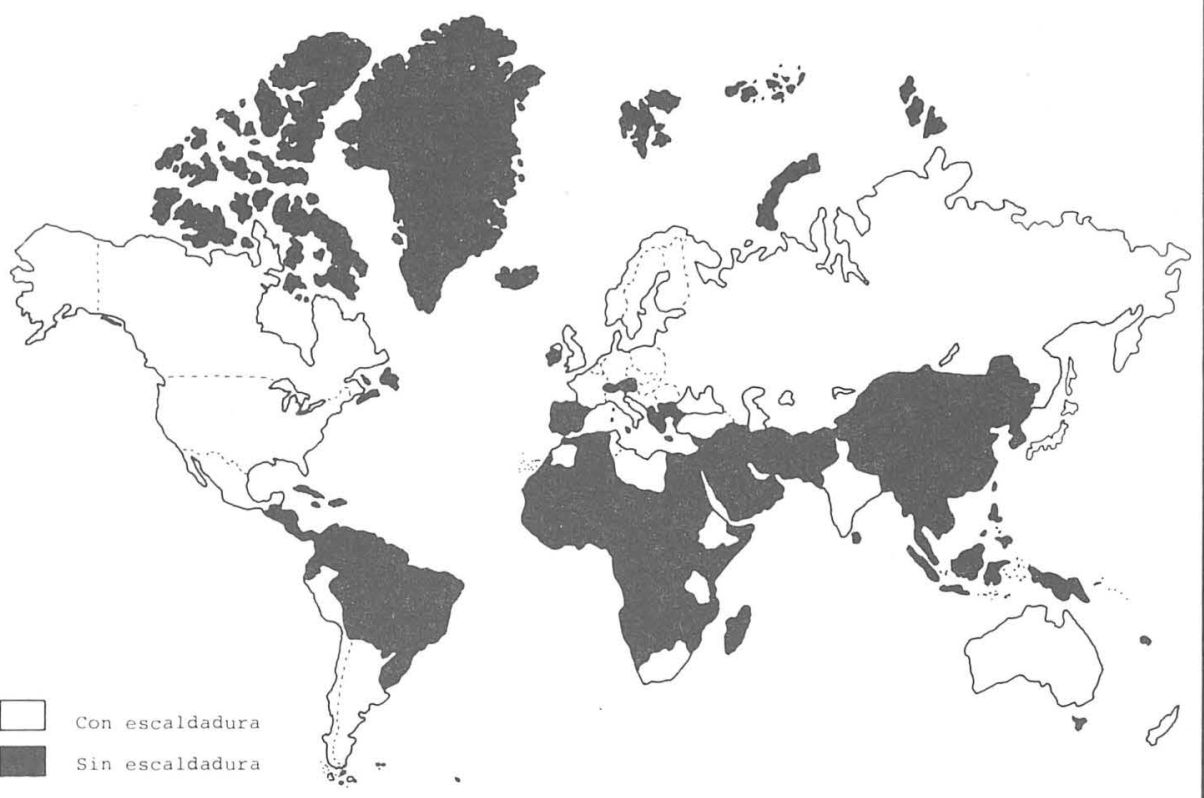

Figura 2. Distribución mundial de la escaldadura de la cebada. 


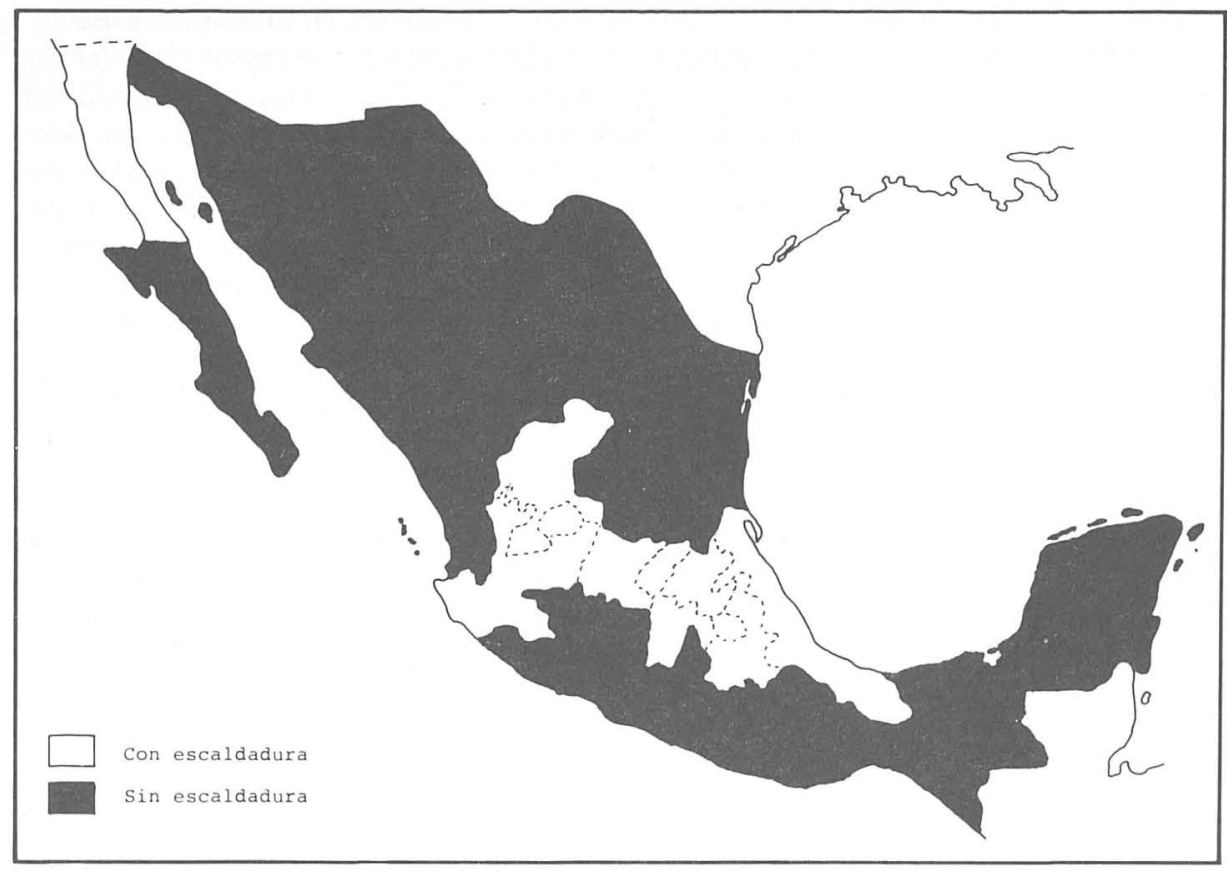

Figura 3. Distribución de la escaldadura de la cebada en la República Mexicana.

Jalisco, Zacatecas (Víctor Rosales, Río Grande y Sombrerete), Veracruz, Guanajuato, Aguascalientes y Querétaro, donde la cebada es de riego y principalmente de invierno.

En la figura 3 se observa la distribución de la escaldadura de la cebada en México.

Como podemos apreciar, la escaldadura de la cebada es una enfermedad de distribución universal, que se ha reportado en 34 países y que es un peligro para el cultivo de este cereal.

AgradeCimientos. Al M. en C. Enrique Riojas Guadiana y al Dr. Manuel Navarro por su información complementaria acerca de la distribución del hongo en México. Al Dr. Carlos de León por su información acerca de la presencia del género en Nicaragua.

\section{LITERATURA CITADA}

Acosta, A., 1973. Present status of the barley crop in Morocco, Proceedings of the Wheat, Triticale and Barley Seminar, International Maize and Wheat Improvement Center. CIMMYT. Anderson, R.G. Ed. El Batán, México, pp. 147-151.

ALI, S.M., 1974. Factors influencing infection, colonization and symptom expression in barley by Rhynchosporium secalis. Aust. J. Agric. Res. 25: 9-20. 
1975 a. Inheritance of scald resistance in barley. I. Resistance genes of group A barley cultivars. Aust. J. Agric. Res. 26: 243-250.

, 1975 b. Inheritance of scald resistance in barley. II. Resistance genes of group B barley cultivars. Aust. J. Agric. Res. 26: 251-257.

, 1981. Barley grass Hordeum leporinum as a source of pathogenic variation in Rhynchosporium secalis (cause of leaf scald). Aust. J. Agric. Res. 32: 21-25.

Andrade Arias, J., 1980. Cebada de grano para temporal en Aguascalientes. INIA, SARH. Campo Agrícola Experimental "El Pabellón", Aguascalientes. Folleto Técnico CAEPAB 1: 1-16.

Australia, Warte-Agric. Research INST.: Biennial report, 1976-1977. Barley. Adelaide, S.A. Australia xiii-184.

BLONSKA-PAWLAK, A. y A. KWIATKOWSKI, 1980. Leaf blotch a dangerous disease of Barley (Rhynchosporium secalis). Ochr. Rostl. V., 24: 6-8.

BOBES, I. y L. SFETCU, 1978. Leaf blotch of barley. Rhynchosporium secalis a severe disease recently recorded in Romania. Probl. Prot. Plant. 6: 57-62.

- 1979. A recently detected disease in barley: Rhynchosporium secalis (spotted leaf). Productia vegetala. Cereale si plante tehnice 31: 39-42.

Cappelli, C. y V. RaGGI, 1981. Observations of two years on barley resistance to Rhynchosporium secalis (Oud.) Davis. Informatore fitopatologico 31: 17-21.

Carvajal, M., 1981. Resumen 092110 del XIII Congreso Internacional de Botánica en Sydney, Australia, 158 PP.

CEOloni, C., 1980. Race differentiation and search for sources of resistance to Rhynchosporium secalis in Barley in Italy. Euphytica 29: 547-553.

Clark, R.V., 1978. Distribution and severity of root and leaf diseases and cereal leaf beetle damage of barley in western Ontario. Can. Plant. Dis. Surv. 58: 33-38.

, W.L. Seaman, K.S. Clough y J.D.E. StiRting, 1979. Leaf blotch on Laurier barley. Can. Plant Dis. Surv. 59: 81-87.

Clough, K.S. y H.W. Johnston, 1978. Cereal diseases in the maritime Provinces, 1977. Can. Plant Dis. Surv. 58: 97-98.

- y K.R. Sanderson, 1979. Barley leaf spots in Prince Edward Island, 1978. Can. Plant. Dis. Surv. 59: 19-21.

Czembor, H.J., E. GaceK y M.M. Kudla, 1979. Characteristics of selected barley varieties with high contents of protein. Hodowla Rosl. Aklim. Nasienn. 23: 269-282.

Daniau, P. Gueguen, J.L. LeCa y P. Prove, 1980. Rimidinne plus, a special fungicide presenting new possibilities for the treatment of growing cereals. Meded. Fac. Landbouwewet Rijksuniv Gent. 45: 277-288.

DhanraJ, K.S., 1970. Alternaria leaf blotch of barley. Indian Phytopatol. 23: 116-117.

Dixit, R.B. y J.S. GuptA, 1980. Studies on the biological control of leaf blotch disease of barley by Streptomyces olivaceus. Acta Bot. Indica 8: 190-192.

DrapatYi, M.O., 1978. Effect of microelements on the infection of barley with leaf blotch caused by Rhynchosporium graminicola. Visn. Sil's 'kohospod. Nauky. 7: 29-31.

DRAPATYI, N.A., 1979. Combined treatment of barley for the control of leaf blotch (Rhynchosporium graminicola) and lodging. Khim. Sel'sk Khoz. 17: 31-34.

EgGUM, S., 1972. Yield variation in continuous cereal growing. Forsk. Fors. Land-bruket. 23: 161-180.

EISENBERG, B.E., 1977. National barley development programme: breeding of new barley cultivars, 1945. (Progress report). Abstract. South Africa Dep. van Landboutegniese Dienste. 1p.

FRASELLE, J., 1974. Study on various methods of treatment against diseases of the aerial parts of winter barley. Results of trialds affected in 1974. Parasitica 30: 167-180.

HANSEN, L.R. y H.A. MagnUS, 1973. Virulence spectrum of Rhynchosporium secalis in Norway and sources of resistance in barley. Phytopathol. 7. 76: 303-313.

Harper, F.R. y L.J. Piening, 1974. Barley diseases in south and central Alberta in 1971: distribution, severity and yield losses. Can. Plant Dis. Surv. 54: 1-5.

Hingorani, M.K., 1971. Report on the Inst. of Agric. Res., Ethiopia, for the period april 1970 to march 1971. Addis Abeba, Etiopía. 140. pp.

Jackson, L.F., A.L. Kahler, R.K. Webster y R.W. Allard, 1978. Conservation of scald resistance in barley composite cross populations. Phytopathology 68: 645-650.

y R.K. WEBSTER R., 1976 a. Race differentiation, distribution and frequency of Rhynchosporium secalis in California. Leaf scald disease of barley. Phytopathology 66: 719-725. 
, 1976 b. Seed and grasses as possible host sources of Rhynchosporium secalis for barley in California. Plant Dis. Rep. 60: 233-236.

Jordan, V.W.L., 1979. Detection and prevention of eyespot (Pseudocercosporella herpetrichoides) and Rhynchosporium secalis (barley). Big Farm Management: pp. 65-68.

KAMPE, W., 1974. Fortified infestation of Rhynchosporium secalis Dav. After chemical control of Erysiphe gra. minis D.C. in summer barley (comunicación preliminar). Sumario en inglés. Original en alemán. Nachrichtenbl. Dtsch. Pflanzenschutz. 26: 148-150.

Khan, T.N. y P.A. Portman, 1979. Breeding a barley resistant to leasf disease. J. Agric. West. Aust. 20: 60-61.

KIEWNICK, L., 1972. A little noticed leaf spot disease of barley and rye Rhymchosporium secalis. Gesunde Pflanz. 24: 139-140.

- 1977. Zum Auftreten von Rhynchosporium secalis an Wintergerste. Gesunde Pflanz. 29: 174-175.

KING, J.E., 1977. Surveys of foliar diseases of spring barley in England and Wales, 1972-1975. Plant Pathol. 26: 21-29.

Kristiansson, B. y B. Nilsson, 1975. Seed-borne diseases on wheat and barley. Sver. Utsadesforen. Tidskr. 85: 163-174.

Kuizenga, J., 1979. Disease control in winter barley. Bestriffsontwikkeling 10: 313-314.

LEWARTOWSKI, R. y A. STUDZINSK1, 1973. Leaf spot disease of barley from Rhynchosporium secalis (Oud.) Davis and its ocurrence in Poland. Ochr. Rostl. 17: 7-9.

LiSKA, M., 1975. Possibilities of chemical protection of barley against Rhynchosporium Scald. Agrochemia 15: 274-277.

Magnus, H.A., 1972. Failure of the barley crop due to leaf spot disease Rhynchosporium secalis. Norsk Landbruk. 22: 4-5.

MAKELA, K., 1972. Leaf spot fungi on barley in Finland. Suomen Maataloustieteellinen Seuran Julk. 124: 1-23.

- 1974. Ocurrence of Rhynchosporium secalis (Oud.) J.J. Davis on spring barley and winter rye in Finland. J. Sci. Agric. Soc. Fin. 46: 103-117.

MAlone, J.P. y H.C. MCGIMPSEY, 1977. Fungicidal control of foliar diseases of barley in Northern Ireland. Mildew Erysiphe graminis, leaf blotch Rhynchosporium secalis. Rec. Agric. Res. North. Irel. Dep. Agric. 25: 45-52.

Marshall, R., J.K. Doodson y J.L. Jemmett, 1971. The reaction of spring barley cultivars to the major foliar disease in disease observation plots in the south west 1967-1971. Jour. Nat. Inst. Agric. Bot. 12: 286-298.

MAyfield, A.H. y B.G. Clare, 1978. A comparison between single-tiller and plot methods for estimating losses in yield on barley with leaf scald disease. Canterbury, Nueva Zelandia, Lincoln College, pp. 1-3.

McBeath, J.H., 1981. Plant Diseases Potential Threat to Delta Alaska, E.U.A. Barley. Agroborealis 13: 38-40.

MCKeEC, R.K., 1973. Annual Rep. on research and technical work of the Ministry of Agriculture for Northern Ireland, 1972. Belfast. Irlanda del Norte, 200 pp.

MCMartin, I., 1977. Northern advisory experience, particulary with reference to Rbynchosporium leaf blotch on barley. Proceedings of a Symposium on Problems of Pest and Disease Control in Northern Britain. pp. 12-14.

Meeus, P., J. Fraselle, P. Gepts y Froidmont, 1978. Trials on the chemical control of leaf blotch [Rhynchosporium secalis (Oud.) Davis] on winter barley. Parasitica 34: 35-48.

Melville, S.C. y C.A. Lanham, 1972. A survey of leaf diseases of spring barley in south-west England. Plant Pathol. 21: 59-66.

Mohamed, H.A., 1975. Plant disease survey in Libya, part I. Diseases of wheat and barley. Libyan J. Agric. 4: 105-107.

Moreno R. y H. Vivar, 1975. Especialización patogénica de Rbynchosporium secalis en los Valles Altos de México. Turrialba 25: 223-225.

Nishimara, N., 1979. Rhynchosporium scald of Lolium multiflorum and Agropyron repens in Japan. Bull. Natl. Grassl. Res. Inst. 15: 103-115.

O'DONNELL, J., 1981. Effect of foliar diseases of spring barley on grain size and weight. Ayr., G.B. T.M. Gemmell and Son Ltd. pp. 15-20.

Pauvert, P., M. Thomas y B. De la Tullaye, 1978. An Attempt at a quatitative interpretation of powdery mildew and Rhynchosporium epidemics. Ann. Phytopathol. 10: 405-416.

PERESYPKIN, V.F. y N.A. Drapatyi, 1977. The penetration and development of the pathogen of rhynchosporiosis in the in the tissues of barley host plants. Mikol. Fitopatol. 11: 335-338.

- 1978. Barley resistance to Rhynchosporium. Dokl. Vaskbnil. 3: 7-9.

PRIESTLEY, R.H. y R.A. BAYLES, 1979. The incidence of Rhynchosporium secalis and Septoria spp. in (wheat, barley and oat) cereal cultivar trials in England and Wales, 1957-1976. J. Nat. Inst. Agric. Bot. 15: 67-75. 
Rafenomananjara D., N. Fraboulet y P. Auriol, 1979. A quantitative estimation of rhynchosporoside produced and degraded in vitro and in vivo. Plant Sci. Letters 14: 337-344.

Ribaldi, M., F. LOREnZetti y S. CeCCARELli, 1974. First observations in Italy on barley leaf spot caused by Rhynchosporium secalis (Oud.) Davis and genetic improvement for resistance. Riv. Patol. Veg. IV, 10: 59-89.

Rivera Peña, A., 1976. Estudio de herencia de la resistencia a la escaldadura, Rhynchosporium secalis (Oud.) Davis en cebada (Hordeum vulgare). Tesis de la Escuela Nacional de Agricultura de Chapingo, Estado de México. 68 pp.

Rodríguez Amieva, P.J. y J.H. Frecha, 1972. Ensayo territorial de enfermedades en trigo, cebada, avena, centeno y lino en la región cerealera argentina en 1971. Bol. Inf. Cent. Invest. Ciencias Agron. Castelar 31: 27.

- y F.L. MÚJICA, 1973. Ensayo territorial de resistencia a enfermedades en trigo, cebada, avena, centeno y lino en la región cerealera argentina en 1972. Bol. Inf. Inst. Nac. Tecnol. Agropec. 32: 24.

SDROvich, H.E., 1977. Rhynchosporium secalis scald of barley varieties. Fajtakiserletezes-fajtaminosites. Orszagos Mezogazdasagi Fajtakiserleti Interzet. 28: 193-199.

Sheridan, J.E. y N. Grbavac, 1977. Cereal diseases 1976-1977. Disease survey in the Wairarapa yield losses and control. Report Bot. Dep. Mycology and Plant Pathology, Victoria, Univ. of Wellington. 9: 79.

Shipton, W.A., W.J.R. Boyd y S.M. Ali, 1974. Scald of barley. Rev. Plant Pathol. 53: 839-861.

SHIPTON, P.J., S.J. WALE y J. O'DONNELL, 1981. Biology and control of Rhynchosporium leaf blotch of spring barley in the north of Scotland. T.M. Gemmell and Son Ltd. Ayr, G.B. pp. 7-13.

SiLJES, I., 1980. Results of controlling some diseases of wheat and barley at the IPK, Osijek. Zast. Bilja. Yugoslavia 31: 357-364.

SKoropad, W.P., 1960. Barley scald in the prairie provinces of Canada. Commonwealth Phytopathol. Newes 6: 25-27.

Smith, N.J.G., 1937. Leaf scald of barley in South Africa. South African J. Sci. 34: 286-290.

Sprague, R., 1950. Some leafspot fungi on Western Gramineae. Mycologia 42: 758-768.

Stedman, J.O., 1978. Cereal diseases. Rothamsted Exp. Stn. Rep. 1977. G.B. Part 1: 212-218, 256-265.

Takats, D., H.E. SDrovich y E. SDrovich, 1980. Ocurrence of the fungus Rhynchosporium secalis (Oud.) Davis on spring and winter barley in Hungary. Novenyvedelem Plant Protection. 16: 8-13.

TAntsyura, A.I., A.Y. Trofimovskay y L.G. ShCHelko, 1980. Immunological properties of barley specimens from the Mediterranean gene centre under Dagestan conditions. Byull. Vses. Nauchno-Issled. Inst. Rastenievod. N.I. Vavilova 104: 62-67.

Tollenafr, H., H. Bleiholder y A. Vera, 1970. New plant diseases observed in Chile. Agric. Tec. 30: 51-54. ZENISCEVA, L. y J. LEKES, 1977. New intensive spring barley genotypes with complex resistance to Erysiphe graminis D.C. Genet Slechteni 13: 13-21. 